\title{
Uncharacterized Protein C15orf65
}

National Cancer Institute

\section{Source}

National Cancer Institute. Uncharacterized Protein C15orf65. NCI Thesaurus. Code C98098.

Uncharacterized protein C15orf65 (121 aa, $14 \mathrm{kDa}$ ) is encoded by the human C15orf65 gene. This protein has no known function. 